\title{
The Effect of Cooperative Letters and Cooperative Posters on the Academic Achievements of Social Studies Teacher Candidates
}

\author{
Sinan AKDAĞ² \\ Atatürk University, Erzurum TURKEY
}

\author{
Emre YILDIZ1 \\ Atatürk University, Erzurum, TURKEY
}

${ }^{1}$ Corresponding author: Dr. Ataturk University, Faculty of Education, Department of Science Education, Erzurum, TURKEY. emre.yildiz@atauni.edu.tr. ORCID: 0000-0001-6396-9183

${ }^{2}$ Research Assistant, Atatürk University, Faculty of Education, Department of Social Sciences Education, Erzurum, TURKEY. sinan.akdag@atauni.edu.tr. ORCID: 0000-0001-5106-7289

\begin{abstract}
The aim of this study is to investigate the effect of cooperative letter and cooperative poster studies on the academic achievement of social studies teacher candidates in contemporary world history course and the relationship between learning writing and course success. In the research, quantitative model was adopted and quasi-experimental design with pretest-posttest comparison groups was used. The study group of the research consists of 78 social studies teacher candidates studying at Atatürk University in the spring semester of 2019-2020. In the research, academic achievement test, letter and poster evaluation rubrics were used as data collection tools. Independent groups ttest and dependent groups t-test were used in the analyzes. As a result of the research, it was determined that cooperative poster and cooperative letter applications are significantly effective in improving the academic achievement of teacher candidates. It was determined that there are no significant difference between the academic achievements of teacher candidates who do different types of writing, but their letter writing skills are significantly higher than their poster preparation skills.
\end{abstract}

\section{Keywords}

Academic Achievement, Cooperative Learning, Letter, Poster, Writing to Learn

To cite this article: Akdağ, S.; Yıldız, E. (2021). The effect of cooperative letters and cooperative posters on the academic achievements of social studies teacher candidates, Review of International Geographical Education (RIGEO), 11(2), 558-573. doi: 10.33403rigeo.799602 
Rapidly developing world has brought new developments in the field of education and these developments have changed the perspectives of researchers doing research in the field of education and thus encouraged them to carry out contemporary studies (Uzoğlu, 2010). Thanks to the new methods and techniques developed to keep up with the needs of the age, the processes of learning information have changed and the ability of the individual to access information has started to gain more importance (Çalsskan, 2008). Instead of acquiring ready knowledge through memorization, teaching methods and techniques, which defend that an individual should access the information and examine it with a critical eye, began to occur (Akçay, Özyurt \& Akçay, 2014). One of the contemporary approaches that emerged in line with the aforementioned purpose is writing to learn.

Calp (2005) defined writing as the process of expressing or communicating one's feelings and ideas onto a paper effectively and in a fine style through a language. Aktaş and Gündüz (2009) described writing as a tool which enables to transfer any feelings and ideas to the future according to a plan by using an effective language. Writing activity which has been acquired as a result of long-term study is both a thinking tool and a skill which enables the feelings and ideas to be expressed in an organized manner via a set of signs and symbols (Gündüz \& Şimşek, 2011). Moreover, writing activity is a learning tool which fosters perception and learning of new concepts (Atila, 2008). Writing activity has a reflective quality and thus it offers students information about their learning processes and helps an individual to consider his own thinking style and understanding (Hamer, 1996). Writing to learn is a condition of learning a concept or a subject by using a writing activity (Emig, 2010). Writing to learn activities are a process of establishing a link between what students known and understand. In this process, students do observation, make predictions, and draw a conclusion throughout writing to learn activities. Knowledge is internalized by the students and finds an opportunity to be applied in this process because students take the responsibility for their learning and make learning meaningful during this process. In addition, writing to learn encourages students to think new ideas by asking questions to themselves, making deductions, and dreaming (Gammill, 2006). Learning-writing activities enable the learner to be active and the teacher to guide, enabling learners to research the topic, increase their knowledge and specialize on the subject. (Akçay, Özyurt, \& Akçay, 2014; Akçay \& Baltacı, 2017; Doğan \& İlhan, 2016; Uzun \& Alev, 2013; Yıldız, 2014). Writing for learning facilitates learning, helps to reinforce what is learned and increases the permanence of information (Bozat \& Yıldız, 2015; Eker \& Coşkun, 2012; Hand, Hohenshell, \& Prain, 2007). In addition to its academic benefits, learning writing activities are an effective learning tool for critical thinking, generating new ideas, developing higher-order thinking and communication skills (Akçay \& Baltacl, 2017; Choi, Notebaert, Diaz, \& Hand, 2010; Doğan \& İlhan, 2016; Klein, 1999; Uzun \& Alev 2013).

When the literature on writing to learn activities is examined, it is seen that a large number of scientific studies have been carried out at home and abroad. Many of the studies are in the field of science and mathematics (Arı ve Yıldırım, 2017; Bereiter ve Scardamalia, 1987; Biber, 2012; Britton, 1972; Boscolo ve Mason, 2001; Çontay, 2012; Emig, 1977; Klein, 1999; Koçak, 2013; Öğdük, 2011; Prain, 2007; 
Rouse, Graham ve Campton, 2017; Tynjala, 1998), and studies in social sciences (Ay, 2018; Boscolo ve Carotti, 2003; Davis, 1990; Friedman ve Patterson, 2011; Fry ve Villagomez, 2012; Kaul, 1998; Karaçağıl, 2014; Langer ve Applebee, 1987; İncirci ve Parmaksız, 2016; Reaves 1991; Stewart, Myers ve Culley, 2010) have been started to be done more in the last 10 years. It is seen that most of the studies given above are in the field of science and mathematics, the studies in social sciences are more limited, and the studies are mostly done with the letter type, which is one of the individual and learning writing activities with student groups at primary and secondary education level. Therefore, in this study, letter and poster activities among learning writing activities were applied to social studies teacher candidates by forming cooperative groups. This study differs from other studies in terms of conducting writing activities in cooperative groups and comparing the effects of the two types of writing and constitutes the original aspect of the research.

The cooperative letter and cooperative poster works discussed within the scope of the research were applied in the teaching of the subjects in the contemporary world history lesson since it was stated in the literature that their subjects were abstract and difficult to learn (Bal, 2011; Erseven, 2011; Ylldı, 2003). The contemporary world history course, taught in the third grade of the old social studies teaching curriculum, was re-included in the program with the same content under the name of new and modern history in the third grade with the renewal of the program. Also shows similarities with both the old and historic area of the Republic of Turkey in the new curriculum classes 1 and 2 from 1919 until 1945, especially on issues concerning Turkey's foreign policy in contemporary world history course. Yazıcı (2018) stated that methods-techniques in which learners are active should be used in the teaching of these subjects. For this reason, it is important to use and compare different methods and techniques in the teaching of these subjects.

The purpose of the research is to investigate the effect of cooperative letter and cooperative poster studies on the academic achievement of social studies teacher candidates in contemporary world history course and the pre-service teachers' writing skills. The problem of the research was identified as follows: "Do cooperative letter and cooperative poster studies have an effect on the academic achievement of pre-service social studies teachers? And are there any differences between the pre-service teachers' writing skills? The study sought to answer the following research questions:

1. Which one is more effective in developing pre-service teachers' academic achievement: cooperative letter or cooperative poster studies?

2. Are cooperative letter or cooperative poster studies effective in increasing reservice teachers' academic achievement?

3. Is there a statistically significant difference between the pre-service teachers' skills of letter writing and poster preparation, types of writing to learn activities? 


\section{Methodology}

\section{Research Design}

The quantitative model has been adopted in the research. Among the experimental designs, a quasi-experimental design with pretest-posttest comparison groups was used (McMillan \& Schumacher, 2006). The most suitable research design is experimental designs for the comparison of effects of two different implementations on academic achievement. Pre-test-post-test comparison group design was adopted in the study because no random assignment to groups and there was no control group and the effects of two different experimental implementations were compared with one another. Because all the variables effective on dependent variables are not controlled in the studies carried out in the field of education, the design becomes a quasi-experimental design. The plan of the experimental design was given in Figure 1.

\begin{tabular}{|c|c|c|c|}
\hline Groups & Pre-test & Implementation & Post-test \\
\hline $\begin{array}{l}\text { - Experimental } \\
\text { Group- } 1 \\
\text { - Experimental } \\
\text { Group- } 2\end{array}$ & - AAT-pre & $\begin{array}{l}\text { - Cooperative } \\
\text { Letter } \\
\text { - Coopeartive } \\
\text { Poster }\end{array}$ & $\begin{array}{l}\text { - AAT-post } \\
\text { - Letter and } \\
\text { poster } \\
\text { evaluation } \\
\text { rubrics }\end{array}$ \\
\hline
\end{tabular}

Figure 1. The experimental design of the research

The study process started with the implementation of Academic Achievement Test (AAT-pre) as pre-test. Cooperative letter writing studies were carried out in Experimental Group-1 and cooperative poster preparation studies were performed in Experimental Group-2. The implementation ended with the administration of Academic Achievement Test (AAT-post) as post-test. The letter and poster works prepared by the preservice teachers were evaluated using letter and poster evaluation rubrics.

\section{Study Group}

The research was conducted with 78 teacher candidates studying at Atatürk University Social Studies Education in the spring semester of the 2019-2020 academic year. Random assignment method was used for the assignment of preservice teachers in experimental groups. Pre-service teachers' names were written on a small piece of paper, folded, and then put in a box. Two lists were formed as Group A and Group B. After drawing a name from the box, it was written in the lists, respectively. The names drawn were put in the box again. Thus, all pre-service teachers' possibilities of being chosen for the groups were equalized. When all the names of the pre-service teachers were drawn, the groups were finalized. Then, writing the group names A and B on a piece of paper, the groups were drawn between themselves, and finally the groups were assigned to experimental groups. As a result, letter writing Experimental Group-1 and poster preparation 
Experimental Group-2 were composed. There are 39 pre-service teachers, 19 female and 20 males, in Experimental Group-1 and Experimental Group-2 consists of a total of 39 pre-service teachers, 23 females and 16 males).

\section{Data Collection Tools}

\section{Academic Achievement Test}

Academic Achievement Test was developed by the researchers to determine the pre-service teachers' preliminary knowledge about research subjects at the beginning of the implementation and the effects of the applied methods on preservice teachers' academic achievement at the end of the implementation. Because there are not tertiary, education gains determined before, learning domains were determined for the subjects included in the research content and a table of specifications was prepared. The researchers prepared a test including 35 items and the test and expert evaluation reports were sent to three domain experts. The domain experts examined the items of the test in many ways in terms of content, property measured, and stylistically. Considering domain experts' opinions, two items were excluded from the test, one item was edited, and the test was arranged systematically. The test's new version including 33 items was administered to 127 social studies teacher candidates who studied these subjects before for piloting. The scale's KR-20 reliability coefficient pilot was calculated as 0.81 in the analysis carried out after the implementations. If the KR-20 reliability coefficient is 0.70 and above, it is possible to say that the measurement process is sensitive and reliable, and the item with a medium difficulty and a discrimination index above 0.30 can be said to be a good item (Oktaylar, 2012). The scale's item difficulty index values ranged between 0,29 and 0,88 and mean difficulty index was calculated as 0,47. The test items' distinctiveness indexes range between 0,30 and 0,82 . The test's final version consisted of 33 items. 3, 03 points are given for the correct answers and 0 is given for the wrong and unanswered questions. One can get minimum 0 and maximum 100 from the test.

\section{Letter and Poster Evaluation Rubrics}

Letter and Poster Evaluation Rubrics were prepared by the researchers to evaluate the writing pieces of pre-service teachers more objectively. The rubrics consist of the criteria including content of writing, appropriate type of writing, spelling and grammar, style and genre, audience appropriateness, knowledge richness and didactic quality. Both rubrics were developed considering 5-point Likert scale and including 10 criteria. If the criteria are fulfilled, one gets 5 points and if the criteria are not fulfilled, one gets 1 point and thus the criteria are scored on a scale of 1 to 5 . The maximum score the groups can get from each writing study is 50 points and the minimum score is 10 points. While determining the total writing scores, the mean scores of all writing were taken and the points were converted to 100 -point scale.

\section{Data Analysis}

The data obtained were tested whether or not they provided assumptions of parametric tests. The normality values of the data were investigated with skewness -kurtosis coefficients, measures of central tendency, and Shapiro-Wilk normality 
Akdağ, S.; Yıldız, E. (2021). The effect of cooperative letters and cooperative posters on the academic..

tests. As a result of analysis, because it was detected that the data were distributed normally, independent samples t-test was used for the data analysis (Field 2013; Shapiro \& Wilk, 1965).

Letter and poster studies were evaluated independently by two researchers. A kappa coefficient of concordance between the two researchers was calculated as 0,77. This value reveals that there is a good concordance between the two researchers (Landis \& Koch, 1977).

\section{Implementation}

The implementation was carried out in both experimental groups by the researchers.

The implementation with the administration of pre-test and post-test lasted 7 weeks (14 course hours). The real implementation lasted 5 weeks (10 course hours). Learning together technique, one of the cooperative leaning models, was used in both groups. At the beginning of the implementation, the pre-service teachers in both experimental groups were divided into 9 groups consisting of four people and one group consisting of three people considering their preliminary knowledge, gender, and socio-economic status. After the groups were composed, the group members came together, and they were given some time to decide group names and logos. The pre-service teachers were given detailed explanations about cooperative learning model and the type of writing to learn activities and the process was introduced.

The groups were informed about the basic elements of cooperative learning and they were warned not to divide the tasks into pieces and combine them or distribute tasks that are independent and disconnected from one another. The Guide for Letter and Poster Preparation and Evaluation Criteria developed by the researchers were shared with the pre-service teachers and they were given detailed explanations. The pre-service teachers' questions about the implementation process were replied and the information process was completed. The pre-service teachers individually did preliminary preparation about the subject of the week before attending the course. The pre-service teachers' preliminary preparation was checked regularly by the researchers. The study portfolio prepared by the researchers was given to each group. The reason why one portfolio was given is to develop a positive dependency among the group members and thus increase communication and sharing. In addition, the pre-service teachers were asked to bring the sources own their own to the classroom. In case of need, they were supported to do research on reliable internet sources. The pre-service teachers performed their group work using the study portfolios, notes they took during their preliminary research, and supplementary resources. The pre-service teachers were supported to carry out tasks such as asking questions and discussions on the subject. During the group work, the researchers walked around the groups, gave extra information, asked questions to the groups, and helped the groups with the questions in their minds. The pre-service teachers completed their studies in the first course hour and then continued with writing to learn activities in the second course hour. The distribution of the subjects according to the weeks during the implementation were presented in Figure 2. 


\section{Week-1}

- Changes in International Affairs

- Strategic Arms Limitation (SALT) Talks

- U-2 Event

- The Cuban Crisis

\section{Week-2}

- The Vietnam War

- Kashmir Issue

- ISoviet Invasion of Afghanistan

- Developments in Non-Aligned Nations

Week-3

- Arab-Israeli Wars

- Camp David Treaty

- The Importnace of Oil in World Politics and 1973 Oil Crisis

- Iran- Iraqi War

\section{Week-4}

- Turkis- Greece Relations in the Era of Détenteé

- Asala

- The Midddle-East Politics of Turkey

- The DepressionYears in Turkey (1960-1983)

\section{Week-5}

- The Disintegration of USSR

- Turkey's Struggle for Independence

- The Foundation of European Union and Turkey-EU Relations

- Asian and African Nations' Struggle for Independence

- Important Social Problems in Turkey and The World

Figure 2. The distribution of the subjects according to the weeks

\section{Letter}

The pre-service teachers in Experimental Group-1 wrote a letter as a writing to learn activity. The letters were written as a group and the groups' works were followed and all group members were made to engage actively in the activity. A letter is a type of writing which states wishes and requests and is sent to a relative or a friend living far away or provides a communication and correspondence between the public institutions. Some of the characteristics of a letter were given below:

- Considering the closeness of the audience to whom a letter is written, the language, wording, and style show differences.

- The letter starts by addressing the person.

- In informal letters, the writer gives information about himself but in formal letters, the purpose of the letter is explained shortly.

- The content of letter includes the problem or concern of the letters. 
- In informal letters, the feelings and emotions are explained in detail. The use of a sincere and friendly language is very important. However, formal letters are short and concise. A formal language is used.

- In Literary and informal letters, greetings that show sincerity and friendship are used or a response to what is written is expected. In formal letters, greeting is shaped according to the status of the writer.

The pre-service teachers were asked to pay attention to the following points while writing a letter:

- Letters must not oppose the Constitution of Turkish Republic, insult any beliefs, and go against basic values.

- $\quad$ Letters must be written on A4 size paper and must be minimum 3 pages and maximum 8 pages.

- The writing paper must be clean and organized.

- The letter written must be designed to teach a subject to a peer.

- The letter must start with a suitable address to a peer.

- A clear, sincere, and intelligible language must be used, and the subject must be narrated considering the letter layout.

- When the letter is sent to a peer, it must be constructed in such a way that he must learn the subject of the course without requiring any other resources.

- The letter must be written considering the characteristics of letters.

- $\quad$ Such elements as graphic, figure, table, picture, etc., could be used in letters. However, the writer must not go out of the frame of letter writing techniques and examples.

\section{Poster}

The pre-service teachers in Experimental Group-2 prepared a poster as a writing to learn activity. The posters were prepared by the groups cooperatively and throughout the process, the groups' studies were followed, and all group members actively engaged in the work. According to the definition of Turkish Language Society (TDK), a poster "is usually a large piece of printed paper with a picture prepared to announce or introduce something and put up in a public space for the people to see". The pre-service teachers were asked to pay attention to the following points while preparing a poster:

- Posters must not oppose the Constitution of Turkish Republic, insult any beliefs, and go against basic values.

- $\quad$ Posters must be prepared on a colorful cardboard in 70*90 size.

- A catchy title that reflects the content of the poster must be used.

- Colorful and attention-grabbing visuals must be used.

- The information given in the poster must be short, clear, and convey the subject matter completely. 
- The information in the poster content must be scientific.

- The balance between the visual elements used in the poster and text must be provided carefully. The posters consisting of a lot of visuals might be poor in terms of knowledge transfer. Similarly, a lot of knowledge could be boring for the reader.

- The person who looks at the poster must learn the subject only with a poster without needing any other source.

\section{Findings}

\section{Findings about the First Research Question}

Independent groups t-test analysis results are given below to determine which of the cooperative letter and cooperative poster works are more effective in improving the academic achievement of teacher candidates.

Analysis results of independent samples t-test administered to determine whether or not there was a statistical difference between the pre-service teachers' preliminary knowledge about the subjects before the implementation were presented in Table-1

Table 1

Independent Samples $t$-Test Results of the Data Obtained from the AAT-pre-test.

\begin{tabular}{lllllll}
\hline Group & $\mathrm{N}$ & $\mathrm{X}$ & $\mathrm{ss}$ & $\mathrm{df}$ & $\mathrm{t}$ & $\mathrm{p}$ \\
\hline Experimental-1 & 39 & 39.10 & 13.99 & \multirow{2}{*}{76} & \multirow{2}{*}{1.363} & \multirow{2}{*}{177} \\
\hline Experimental-2 & 39 & 34.49 & 15.84 & & & \\
\hline
\end{tabular}

As seen from the results of data analysis in Table 1, there is not a statistically significant difference between the preliminary knowledge of pre-service teachers who performed cooperative letter and poster studies $\left(t_{(76)}=1.363, p>.05\right)$. The analysis results of independent samples t-test administered at the end of the study to determine the effects of cooperative letter and poster studies on pre-service teachers' academic achievement were presented in Table- 2 .

Table 2

Independent Samples $t$-Test Results of the Data Obtained from the AAT-post-test

\begin{tabular}{lllllll}
\hline Group & $\mathrm{N}$ & $\mathrm{X}$ & $\mathrm{ss}$ & $\mathrm{df}$ & $\mathrm{t}$ & $\mathrm{p}$ \\
\hline Experimental-1 & 39 & 76.03 & 13.58 & \multirow{2}{*}{76} & \multirow{2}{*}{.076} & .940 \\
\cline { 1 - 5 } Experimental-2 & 39 & 75.77 & 16.08 & & & \\
\hline
\end{tabular}

According to the analysis results presented in Table 2, it was determined that there was not a statistically significant difference between the academic achievements of the pre-service teachers who performed cooperative letter and poster studies $\left.\left(\mathrm{t}_{(76)}\right)=.076, \mathrm{p}>.05\right)$.

\section{Findings about the Second Research Question}

The analysis results of the dependent groups t-test conducted to determine whether cooperative letter and cooperative poster works are effective in increasing the academic achievement of prospective teachers are given below. 
Akdağ, S.; Yıldız, E. (2021). The effect of cooperative letters and cooperative posters on the academic..

Analysis results of dependent samples t-test administered to determine the effect of cooperative letter writing on the pre-service teachers' academic achievement were presented in Table-3

Table 3

Dependent Samples t-Test Results of Cooperative Letter Writing

\begin{tabular}{lllllll}
\hline Test & N & X & ss & df & t & p \\
\hline Pre-test & 39 & 39.10 & 13.99 & \multirow{2}{*}{38} & \multirow{2}{*}{-10.470} & .000 \\
\hline Post-test & 39 & 76.03 & 13.58 & & & \\
\hline
\end{tabular}

Considering the analysis results in Table 3, it was revealed that cooperative letter writing study increased pre-service teachers' academic achievement significantly $\left(\mathrm{t}_{(38)}=-10.470, \mathrm{p}<.05, \eta^{2}=.74\right) .74 \%$ of the variance observed with the pre-service teachers' academic achievement results from the cooperative letter writing studies. According to Cohen (1988), this value is considered as large effect.

Analysis results of dependent samples t-test administered to determine the effect of cooperative poster preparation on the pre-service teachers' academic achievement were presented in Table-4.

Table 4

Dependent Samples t-Test Results of Cooperative Poster Preparation

\begin{tabular}{lllllll}
\hline Test & $\mathrm{N}$ & $\mathrm{X}$ & $\mathrm{ss}$ & $\mathrm{df}$ & $\mathrm{t}$ & $\mathrm{p}$ \\
\hline Pre-test & 39 & 34.49 & 15.84 & \multirow{2}{*}{38} & -13.048 & \multirow{2}{*}{000} \\
\hline Post-test & 39 & 75.77 & 16.08 & & & \\
\hline
\end{tabular}

Considering the analysis results in Table 4, it was determined that cooperative poster preparation study increased pre-service teachers' academic achievement significantly $\left(\mathrm{t}_{(38)}=-13.048, \mathrm{p}<.05, \eta^{2}=.82\right) .82 \%$ of the variance observed with the pre-service teachers' academic achievement results from the cooperative letter preparation study. According to Cohen (1988), this value is considered as large effect.

\section{Findings about the Third Research Question}

Analysis results of independent samples t-test administered to determine whether or not there was a statistically significant difference between the preservice teachers' cooperative letter writing and cooperative poster preparation skills were presented in Table-5.

Table 5

Independent Groups t-Test Results for Letter Writing and Poster Preparation Skills

\begin{tabular}{lllllll}
\hline Group & $\mathrm{N}$ & $\mathrm{X}$ & $\mathrm{ss}$ & $\mathrm{df}$ & $\mathrm{t}$ & $\mathrm{p}$ \\
\hline Experimental-1 & 39 & 81.32 & 6.09 & \multirow{2}{*}{76} & \multirow{2}{*}{3.318} & \multirow{2}{*}{001} \\
\hline Experimental-2 & 39 & 76.59 & 6.48 & & & \\
\hline
\end{tabular}

When the analysis results presented in Table 5 were examined, it was found that the pre-service teachers' cooperative letter writing skills were statistically and significantly' higher than cooperative poster preparation skills $\left(\mathrm{t}_{(76)}=3.318, \mathrm{p}<.05\right.$, $\eta^{2}=.13$ ). $13 \%$ of the variance observed with the pre-service teachers' writing to learn 
skills result from the types of writing. According the classification of Cohen (1988), this value was considered medium effect.

\section{Result and Discussion}

It was determined that there was not a statistically significant difference between the pre-service teachers' academic achievement in the study carried out to explore the effects of cooperative letters and cooperative poster studies on the pre-service social studies teachers' academic achievement in contemporary world history course and the pre-service teachers' writing skills. It can be stated that because the pre-service teachers worked together, had group discussions, completed each other's deficiencies, subjectified information in the letter content, and used cognitive processes actively and effectively during the transformation of poster content into a brief form, both implementations increased academic achievement at a similar ratio. Similar to the result of this research, in studies examining the effect of success on the General Physics Laboratory III course, no significant difference was determined between cooperative brochures and cooperative postcard applications (Yıldız, Koçak, Ürün-Arıcı \& Şimşek, 2018), between cooperative story and cooperative poster applications (Yıldız, 2021a) and cooperative story and collaborative comic book applications (Ylldı, 2021b).

It was determined that cooperative letter writing increased the pre-service teachers' academic achievement statistically at a significant level. It can be stated because the pre-service teachers worked in groups, had group discussions and asked questions in their minds to their peers, group members completed each other's deficiencies, and subjectified information in the letter content and transferred the information with a sincere and friendly language, digesting and transforming knowledge increased achievement. It was determined that cooperative poster preparation increased the pre-service teachers' academic achievement statistically at a significant level. The pre-service teachers' academic achievement could have increased due to the following reasons such as group works of pre-service teachers, groups discussions, asking questions in their minds to their peers, group members' completing deficiencies of one another, transferring knowledge in the poster content briefly, objectively, and clearly, and the more use of cognitive processes by the pre-service teachers while generating the content. The results obtained from this study are compatible with other research results indicating that different types of writing increase achievement in the literature (Alharbi, 2015; Akcanca and Cerrah-Özsevgeç, 2019; Akçay, Özyurt and Akçay, 2014; Ashworth, 1992; Atasoy, 2013; Atila, 2008; Atila, Günel and Büyükkasap, 2010; Ay and Başıüyük, 2018; Bozat, 2014; Burton and Morgan, 2000; Cavkaytar, 2010; Daşdemir, 2014; Daşdemir, 2018; Doğan and İlhan, 2016; Duymaz, 2011; Eker and Coşkun, 2012; Günel, Hand and Gündüz, 2006; Günel, Uzoğlu and Büyükkasap, 2009; Hand and Choi, 2010; Karaçağıl, 2014; Karaçağıl and Avaroğulları 2017; Koçak, 2013; Koçak and Seven, 2016; Uzoğlu, 2010; Uzoğlu, 2014; Uzun, 2011; Uzun and Alev, 2013; Yıldız, 2009; Yıldız and Büyükkasap, 2011

It was determined that the pre-service teachers' cooperative letter writing skills were significantly higher than poster preparation skills. Because the letter content was more detailed than poster, the pre-service teachers could convey the content 
more easily. In addition, they had difficulties with presenting core information and providing the balance between the information and the visuals in the posters. Thus, the pre-service teachers must have been more successful in letter writing. Unlike this study, Ylldız (2021a) reached the conclusion that there is no significant difference between the scores of prospective teachers for story and poster writing activities.

\section{Suggestions}

In line with the results obtained from the study, the use of activities such as cooperative letters and cooperative posters that provide more concrete contents especially in the teaching of abstract courses such as contemporary world history can be offered as a suggestion for studies to be conducted. In addition, the reasons why the cooperative letter activity that emerged as a result of the research gives more positive results than the cooperative poster activity can be suggested as a new research topic for researchers.

\section{References}

Akcanca, N. and Özsevgec, L. C. (2019). Preschool teacher candidates' views on the evaluation of reflective diaries. Mediterranean Journal of Educational Research, 13 (28), 214-233.

Akçay, H., \& Baltacl, A. (2017). Evaluation of multiple writing activities for learning in astronomy teaching. Mersin University Journal of Education Faculty, 13 (1), 138-151.

Akçay, H., Özyurt, B.B. and Bezir Akçay, B. (2014). The effect of using multiple writing activities in science and technology lesson teaching on student achievement and concept learning. Bayburt University Journal of Education Faculty, 10 (2), 15-31.

Aktaş, Ş. and Gündüz, O. (2009). Written and oral expression, reading - listening - speaking - writing. Akcay Publishing. Ankara.

Alharbi, F. (2015). Writing for learning to improve students' comprehension at the college level. English Language Teaching, 8(5), 222-234.

Arı, A. A., \& Yıldırım, Z. (2017). The effect of writing activities on the academic success of middle school students in algebraic expressions. Social Sciences Studies Journal, 3 (12), 2011-2019.

Ashworth, T. E. (1992). Using writing-to-learn strategies in community college associated degree-nursing programs (Doctoral dissertation). Retrieved from https://vtechworks.lib.vt.edu (osu LD5655.V856_1992.A849).

Atasoy, S. (2013). Effect of writing-to-learn strategy on undergraduates' conceptual understanding of electrostatics effect of writing-to-learn strategy on undergraduates' conceptual understanding of electrostatics. The Asia-Pacific Education Researcher, 22(4), 593-602.

Atila, M. E. (2008). The effects of the use of different description modes in learning writing activities on academic achievement in science teaching. Unpublished Master Thesis. Atatürk University, Institute of Science Erzurum.

Atila, M. E., Günel, M., Büyükkasap, E. (2010). The effect of variations on the use of description modes in learning writing activities on the learning of elementary force and motion subjects. Turkish Journal of Science Education. 7, 113-127. 
Ay, A. (2018). The effect of the use of letters and poetry among learning writing activities on student achievement in social studies curriculum. Unpublished Doctoral Thesis. Erzincan University, Institute of Social Sciences Erzincan.

Ay, A., \& Başıüyük, A. (2018). The opinions of social studies teacher candidates about writing activities for learning purposes. Erzincan University Journal of Social Sciences Institute, 11 (1), 33-42.

Bal, M. S. (2011). A comparison of teachers and teacher discuss problems and solutions to the teaching of history in Turkey. Mustafa Kemal University Journal of Social Sciences Institute, 8 (15), 371-387.

Bereiter, C., \& Scardamalia, M. (1987). The psychology of written composition. Hillsdale, NJ, US: Lawrence Erlbaum Associates Inc.

Boscolo, P., \& Carotti, L. (2003). Does writing contribute to improving high school students' approach to literature? Educational Studies in Language and Literature, 3, 197-224.

Boscolo, P., \& Mason, L. (2001). Writing to learn, writing to transfer. G. Rijlaarsdarn (Series Ed.) \&

Bozat, Ö. (2014). 5. The effect of the letter on the success of writing activities for learning purposes in the electrical unit in our classroom life. Unpublished Master Thesis. Atatürk University, Institute of Educational Sciences, Erzurum.

Bozat, Ö. and Yıldız, A. (2015). 5. The effect of the letter on the success of writing activities for learning purposes in the electrical unit in our classroom life. Education Sciences, 10 (4), 291-304.

Britton, J. N. (1972). Writing to learn and learning to write. Document Resume, 200(145), 31.

Burton, L., Morgan, C. (2000). Mathematicians writing. Journal for Research in Mathematics Education. 31, 429-453.

Çalışkan, H. (2008). Educators' perceptions about the inquiry-based learning approach. Gazi Faculty of Education Journal, 28 (1), 153-170.

Calp, M. (2005). Teaching Turkish as a special education area. Education Bookstore Publications. Konya.

Cavkaytar, S. (2010). Using the writing process model in developing written expression skills in primary education. International Journal of Social Research, 3-10.

Choi, A., Notebaert, A., Diaz, J., and Hand, B. (2010). Examining arguments generated by year 5, 7, and 10 students in science classrooms. Res Sci Educ, 40,149-169.

Çontay, E. G. (2012). The effect of writing activities on surface areas and volumes of geometric objects on the success of 8th grade students and their self-efficacy towards geometry. Unpublished Master Thesis. Pamukkale University, Institute of Educational Sciences Denizli.

Daşdemir, İ. (2014). The effect of letter-writing activities for learning purposes on them students' learning of the science course and scientific attitude, Educational Research and Reviews 9 (19), 786-791.

Davis, B. H. (1990). The effects of expressive writing on the social studies achievement, writing fluency, and learning retention of fourth-grade students (Doctoral dissertation). Retrieved from ProQuest Dissertations and Theses Global. (UMI No. 9104761)

Doğan, Y. and İlhan, N. (2016). Prospective Teachers' Views Related to Using Writing to Learn Activities in "Science and Technology Teaching" Course. Adlyaman University Journal of Educational Sciences, 6 (1), 1-22. 
Akdağ, S.; Yıldız, E. (2021). The effect of cooperative letters and cooperative posters on the academic..

Duymaz, N. (2011). The use of learning writing activities and analogy in learning the cell subject. Unpublished Master Thesis. Gazi University, Institute of Educational Sciences Ankara.

Eker, C. and Coşkun, İ. (2012). The effect of writing a course diary on the academic success of primary school 4th grade students in social studies course. Muğla Sitkı Koçman University Journal of Social Sciences Institute, 29, 110-120.

Emig, J. (1977). Writing as a mode of learning. College Composition and Communication, 28, 122-28.

Erseven, E. (2011). Evaluation of the 12th grade "Contemporary Turkish and World History" textbook in the light of teachers and students' opinions. Unpublished Master Thesis. Gazi University, Institute of Educational Sciences Ankara.

Field, A. (2013). Discovering statistics using IBM SPSS (4th ed.). Thousands Oaks, CA: Sage.

Friedman, V. S., and Patterson, L. M. (2011). Writing in geography: student attitudes and assessment. Journal of Geography in Higher Deducation, 36(2), 179-195.

Fry, W. S., and Villagomez, A. (2012). Writing to learn: benefits and limitations. College Teaching, 60(4), 170-175.

Gammill, D. M. (2006). Learning the write way. The Reading Teacher, 59(8), 754-762.

Gündüz, O., and Şimşek, T. (2011). Applied writing education. Graphic Publications. Ankara.

Günel, M., Hand, B. and Gündüz, Ş. (2006). Comparing student understanding of quantum physics when embedding multimodal representations into two different writing formats: presentation format versus summary report format. Science Education, 90, 1092- 1112.

Günel, M., Uzoğlu, and M., Büyükkasap, E. (2009). The effect of the use of learning writing activities on learning the subject of force at primary education level. Gazi Faculty of Education Journal, 29 (1) 379-399.

Hammer, D. (1996). How many alternative perspectives of cognitive structure influence instructional perceptions and intentions? Journal of Learning Sciences. 5, (2), 97-127

Hand, B. and Choi, A. (2010). Examining the impact of student use of multiple modal representations in constructing arguments in organic chemistry laboratory classes. Research in Science Education, 40, 29-44.

Hand, B., Hohenshell, L. and Prain, V. (2007). Examining the effect of multiple writing tasks on year 10 biology students' understanding of cell and molecular biology concepts. Instructional Science, 35, 343-373.

İncirci, A., and Parmaksız, R. Ş. (2016). The effects of writing to learn (WTL) on academic achievement and attitude to lesson in English classes. Universal Journal of Educational Research 4(9), 2163-2173.

Karaçağll, C. (2014). The effect of using writing activities for learning in social studies lessons on academic achievement of students. Unpublished Master Thesis. Muğla Sıtkı Koçman University, Institute of Educational Sciences Muğla.

Karaçağıl, C. and Kiriş Avaroğulları, A. (2017). The effect of using writing activities for learning in social studies lessons on students' academic success. International Journal of Innovative Research in Education, 4 (2), 54-59.

Kaul, M. V. (1998). The effects of the use of writing as a teaching and learning tool on the achievement of freshman economics students (Doctoral dissertation). Retrieved from ProQuest Dissertations \& Theses Global. (UMI No. 9901340) 
Klein, P. D. (1999). Reopening inquiry into cognitive processes in writing-to-learn. Educational Psychology Review,11 (3), 203-270.

Koçak, G. (2013). The effect levels on the academic success and permanence of 1st grade students in science teaching by applying writing activities for learning in one dimension about movement. Unpublished Master Thesis. Atatürk University, Institute of Educational Sciences. Erzurum.

Koçak, G., and Seven, S. (2016). The opinions of pre-service science teachers about writing activities for learning purposes: example of movement in one dimension. Ekev Academy Journal, 20 (65), 253-268.

Landis J.R., and Koch G. G. (1977). The measurement of observer agreement for categorical data. Biometrics, 33(1), 159-74.

Langer, J. A. and Applebee, A. N. (1987). How writing shapes thinking. Urbana, Illinois: National Council of Teachers of English.

Mcmillan, J. H. and Schumacher, S. (2006). Research in education: Evidence-Based inquiry. (6th ed.). Boston, MA: Allyn and Bacon.

Öğdük, A. (2011). The effect of modal descriptions used in learning writing activities in science and technology lesson in the second level of primary education on academic achievement. Unpublished Master Thesis. Atatürk University, Institute of Educational Sciences, Erzurum.

Oktaylar, H. C. (2012). Quantification and consideration. Yargl Publishing House,Ankara.

Tynjala, P. L. (1998). Studies in Writing, Writing as a Learning Tool: Integrating Theory and Practice (pp. 83 - 104). Netherlands: Kluwer Academic Publishers.

Pepper, B. (2012). Science and technology teachers' perceptions of writing and their level of application of learning writing activities. Unpublished Master's Thesis. Atatürk University, Institute of Educational Sciences, Erzurum.

Prain, V. (2006). Learning from writing in secondary science: some theoretical and practical implications. International Journal of Science Education, 28(2-3), 179-201.

Reaves, R. R. (1991). The effects of writing to learn activities on the content knowledge, retention of information and attitudes toward writing of selected vocational agriculture education students (Doctoral dissertation). Retrieved from ProQuest Dissertations \& Theses Global. (UMI No. 9130824)

Rouse, A. G., Graham, S. and Compton, D. (2017). Writing to learn in science: Effects on grade 4 students' understanding of balance. The Journal of Educational Research, 110(4), 366-379.

Shapiro, S.S., and Wilk, M.B. (1965). An analysis of variance test for normality (complete samples). Biometrika, 52(3/4), 591-611.

Stewart, T. L., Myers, A. C. and Culley, M. R. (2010). Enhanced learning and retention through "writing to learn" in the psychology classroom. Teaching of Psychology, 37(1), 46-49.

Tynjala, P. (1998). Writing as a tool for constructive learning: Students' learning experiences during an experiment. Higher Education, 36(2), 209-230.

Tynjälä, P., Mason, L., \& Lonka, K. (Ed.). (2012). Writing as a learning tool: Integrating theory and practice (7th ed.). New York: Springer.

Uzoğlu, M. (2010) Investigation of the effect of using writing activities for learning purposes on learning force and matter unit at primary education level. Unpublished Doctorate Thesis, Atatürk University Institute of Science Erzurum. 
Uzoğlu, M., (2014). Determining the effects of using different writing activities on the academic Achievements, secondary school 7th grade students and their attitudes towards the course. Eucational Research and Reviews, 9 (20), 1065-1070.

Uzun, S. (2011). The effect of learning environments enriched with literacy activities on physics learning: a 98 application in energy unit. Unpublished Doctoral Thesis. Karadeniz Technical University, Institute of Educational Sciences, Trabzon.

Uzun, S. and Alev, N. (2013). The effect of learning environments enriched with literacy activities on student achievement. Turkish Journal of Science Education, 10 (2), 138154.

Yazıcı, Ș. (2018). Contribution of Contemporary Turkish and World History achievements to critical thinking skills according to teachers' views. Unpublished Master Thesis. Sivas Cumhuriyet University, Institute of Educational Sciences Sivas.

Yıldız, A. (2014). Letter and its effective use as a learning writing activity. Journal Turkish Studies, 9 (5), 2097-2097.

Yıldız, A., and Büyükkasap, E. (2011). Pre-service teachers' levels of understanding of photo electricity and the effect of writing to learn on success. Educational Sciences: Theory and Practice, 11 (4), 2259-2274.

Yıldız, E. (2021a). The effects of cooperative story and poster applications on academic success of pre-service science teachers. Marmara University Atatürk Faculty of Education Journal of Educational Sciences, 53 (53), 342-362.

Yıldız, E. (2021b). Comparison of the effects of cooperative story and comic writing on the academic success of pre-service teachers. Journal of Ahi Evran University Institute of Social Sciences, 7 (1), 32-49.

Yıldız, E., Koçak, G., Ürün Arıcı, N. and Şimşek, Ü. (2018). The effects of cooperative learning and writing activities for learning purposes on prospective teachers' achievement in physics laboratory and writing skills for learning. 27th Educational Sciences Congress.

Yıldız, Ö. (2003). Contemporary problems and suggest solutions to the teaching of history in Turkey. Erciyes University Journal of Social Sciences Institute, 1 (15), 181-190.

Yıldız, Ö. (2009). Understanding of quantum physics topics of university students and the effect of learning writing activities on academic success. Unpublished Doctoral Thesis. Atatürk University, Institute of Science, Erzurum.

\section{Biographical Statements}

Sinan AKDAĞ is a Researcher Assistant at the Faculty of Education in Atatürk University, where he is Social Science Education Department. His research interest includes Social Studies education, cooperative learning and writing to learn.

Emre YILDIZ is a Doctor at the Department of Science Education at the Atatürk University. His research interest includes Science education, educational games, cooperative learning and writing to learn. 